\title{
Evaluating Policy Approaches Towards Tackling Undeclared Work in the Czech Republic
}

Colin C. Williams*, Gamze Oz Yalaman*", Abbi M. Kedir ${ }^{* \star \star}$

\section{Summary}

This paper evaluates two competing theories for explaining and tackling undeclared work. The dominant rational economic actor approach views undeclared work as arising when the perceived benefits of engaging in undeclared work outweigh the costs, so attention is put on increasing the costs, whilst the more recent social actor approach views undeclared work to result from the lack of citizens' commitment to compliance and thus attempts to enhance vertical and horizontal trust. To evaluate these theories, 1,024 and 1,000 face-to-face interviews undertaken in 2007 and 2013 with a representative sample in the Czech Republic are analysed. The finding is that higher perceived penalties and risks of detection have no significant impact on the likelihood of conducting undeclared work. In contrast, the level of vertical and horizontal trust have a significant impact on engagement in undeclared work; the higher the vertical and horizontal trust, the lower is the likelihood of participation in undeclared work. The theoretical implication is that this evidence supports a new social actor approach. The policy implication is that the rational economic actor approach of increasing the penalties and risks of detection appears ineffective, and a new policy approach is proposed focused on improving vertical and horizontal trust.

Keywords: informal sector, undeclared work, shadow economy, tax morale, Czech Republic

JEL: H26, J46, K42, O17, P37

\section{Introduction}

In recent decades, there has been recognition that undeclared work is not only extensive but also growing rather than declining in many countries and global regions (Williams, 2014, 2020a; Williams and Horodnic, 2020; Williams and Schneider, 2016). Indeed, in the European Union, Schneider (2016) estimates undeclared work to be equivalent to $17.9 \%$ of the Gross Domestic Product (GDP) in 2016. This has significant negative consequences. Economies lose competitiveness due to productive registered formal enterprises suffering unfair competition from unproductive unregistered enterprises (Leal Ordóñez, 2014), governments lose tax revenue that could fund public goods and services (Bajada and Schneider, 2005),

\footnotetext{
The University of Sheffield - Management, Management School

** Eskişehir Osmangazi University - Finance Department. Meşelik-Eskişehir, Turkey

${ }^{* \star *}$ The University of Sheffield - Management School
} 


\section{Articles}

and customers lack legal recourse and certainty that health and safety regulations have been followed (Williams and Martinez, 2014). Undeclared workers, moreover, lack entitlement to labour rights such as the minimum wage and sick pay, cannot build up rights to the state pension and access occupational pension schemes, and lack access to health and safety standards as well as bargaining rights and voice (Andrews et al., 2011; European Commission, 2007).

The aim of this paper is to evaluate two contrasting approaches towards explaining and tackling undeclared work and whether they can be combined. In doing so, knowledge is advanced in three ways. Theoretically, an evaluation is undertaken of firstly, the dominant rational economic actor approach which views undeclared work to arise when the perceived benefits of engaging in undeclared work outweigh the costs of doing so and secondly, the more recent social actor approach, grounded in institutional theory, which views undeclared work to result from the lack of vertical and horizontal trust. Importantly, an evaluation is also conducted of whether these approaches can be combined and if so, how. Empirically, data is reported for the first time from 1,024 and 1,000 face-to-face interviews conducted in 2007 and 2013 respectively with a representative sample of the population of the Czech Republic. Third and finally, and in terms of policy, a new approach is proposed. Rather than focus upon increasing penalties and the risk of detection, which is shown as ineffective, a focus upon policy initiatives that improve vertical and horizontal trust is revealed as more effective.

Therefore, to commence, the next section reviews the rational economic actor and social actor approaches towards explaining and tackling undeclared work and whether they can be combined. The third section then introduces the data and methodology to evaluate these approaches, namely a logistic regression analysis of face-to-face interviews conducted in Czech Republic during 2007 and 2013. The fourth section reports the findings. This reveals no association between participation in undeclared work and the perceived level of penalties and risk of detection, but a significant positive association between participation in undeclared work and the level of vertical and horizontal trust. In the fifth and final section, the implications for theory and policy are then discussed.

Before commencing, however, undeclared work must be defined. Reflecting the consensus among academics and practitioners, undeclared work here refers to paid activity that is legal in all respects other than it is not declared to the authorities for tax, social security or labour law purposes, when it should be declared (Aliyev, 2015; Boels, 2014; European Commission, 2007; Hodosi, 2015; OECD, 2012; Williams, 2014a,b; Williams and Windebank, 1998). If it is not legal in all other respects, it is not defined as undeclared work. If the goods or services traded are illegal for instance (e.g., illegal drugs), then it is not part of the undeclared economy, but the wider criminal economy.

\section{Preventing undeclared work: a review of competing explanations and policy approaches}

A review of the extensive literature on how to explain and tackle undeclared work reveals the existence of two contrasting theoretical approaches. Here, each is examined in turn and whether they are mutually exclusive.

\section{Rational economic actor approach}

The origins of the rational economic actor approach lie in the classic utilitarian theory of crime that explains citizens as participating in crime when the expected costs (i.e., the likelihood of being caught and sanctions) do 


\section{Articles}

not outweigh the benefits (Bentham, 1788). During the late 1960s, this was popularised by Becker (1968) who argued that acting lawfully would become the rational choice for citizens if governments increased the level of sanctions and likelihood of detection. A few years later, Allingham and Sandmo (1972) applied this approach to tax non-compliance, arguing that non-compliance occurred when the benefits outweighed the expected costs.
Evaluating Policy Approaches Towards Tackling

Undeclared Work in the Czech Republic

Table 1. Studies of rational economic actor approach

\begin{tabular}{|c|c|c|}
\hline Relationship & Result & Studies \\
\hline \multirow[t]{4}{*}{$\begin{array}{l}\text { Relationship between } \\
\text { increasing the perceived } \\
\text { penalties and risks of detection } \\
\text { and participation in undeclared } \\
\text { work }\end{array}$} & Reduces participation & $\begin{array}{l}\text { Dubin and Wilde, 1988; Feld and Frey, 2002; Friedland, 1982; Friedland et } \\
\text { al., 1978; Klepper and Nagin, 1989; Mazzolini et al., 2017; Schwartz and } \\
\text { Orleans, 1967; Slemrod et al., 2001; Webley and Halstead, 1986; Witte } \\
\text { and Woodbury, } 1985\end{array}$ \\
\hline & $\begin{array}{l}\text { Risk of detection } \\
\text { reduces participation } \\
\text { more than penalties }\end{array}$ & $\begin{array}{l}\text { Alm, 1999; Friedland, 1982; Webley and Halstead, 1986; Williams, and } \\
\text { Horodnic 2017a,b }\end{array}$ \\
\hline & No effect & Hartl et al., 2015; Shaw et al., 2008; Williams and Franic, 2015, 2016 \\
\hline & $\begin{array}{l}\text { Increases non- } \\
\text { compliance }\end{array}$ & $\begin{array}{l}\text { Chang and Lai, 2004; Hofmann et al., 2017; Kaplanoglou and Rapanos, } \\
\text { 2015; Kaplanoglou et al., 2016; Mohdali et al., 2014; Murphy, 2005, 2008; } \\
\text { Murphy and Harris, } 2007\end{array}$ \\
\hline
\end{tabular}

Despite its widespread adoption by governments (see Williams and Puts, 2017), the evidence that increasing the risks of detection and penalties reduces participation in undeclared work is mixed. Some studies find that increasing the probability of detection and/or the sanctions level reduces participation in undeclared work (Dubin and Wilde, 1988; Feld and Frey, 2002; Friedland, 1982; Friedland et al., 1978; Klepper and Nagin, 1989; Mazzolini et al., 2017; Schwartz and Orleans, 1967; Slemrod et al., 2001; Webley and Halstead, 1986; Witte and Woodbury, 1985). Indeed, a meta-analysis of twenty laboratory experiments with students in the United States, Central America, Europe and Israel, concludes that increasing the penalty and the probability of audits increases compliance (Blackwell, 2010). Similarly, macro-level studies, analyzing secondary data at country or regional level,
To alter the cost/benefit ratio confronting taxpayers, they argued for an increase in the actual and/or perceived risks of detection and sanctions. Subsequently, this rational actor approach has been widely adopted as a way of explaining and tackling undeclared work (Grabiner, 2000; Hasseldine and Li, 1999; Richardson and Sawyer, 2001). Table 1 summarises the studies and their findings. 


\section{Articles}

most important critique of this approach is the finding that many citizens voluntarily comply even when the level of penalties and risk of detection would suggest that they should not if they were truly rational economic actors (Murphy, 2008). In consequence, to evaluate this rational economic actor approach, the following hypothesis can be tested:

\section{Rational economic actor hypothesis} (H1): increasing the perceived penalties and probability of detection lowers the likelihood of participation in undeclared work, ceteris paribus.

H1a: increasing the perceived penalties lowers the likelihood of participation in undeclared work, ceteris paribus.

$H 1 b$ : increasing the perceived probability of detection lowers the likelihood of participation in undeclared work, ceteris paribus.

\section{Social actor approach}

The finding that many citizens do not engage in undeclared work even when the benefits outweigh the costs (Alm et al., 2010; Murphy, 2008) has led to a new approach to explaining and tackling undeclared work. Drawing inspiration from a variant of institutional theory (Helmke and Levistky 2004; North 1990), a social actor approach has emerged as a new way of explaining and tackling undeclared work (Williams, 2020b; Williams and Horodnic 2015; Williams et al., 2015). This explains undeclared work to result from formal institutional imperfections that produce an asymmetry between the codified laws and regulations of a society's formal institutions ('state morality') and the socially shared unwritten rules of its informal institutions ('civic morality'). This asymmetry reflects the level of vertical trust and can be measured using the level of tax morale (i.e. the intrinsic motivation to pay taxes). The goal, therefore, is to engender a commitment of the population to self-regulate by improving their tax morale (Kirchler 2007; Torgler 2007, 2011).

Indeed, studies in different European countries (Williams and Franic 2015, 2016; Williams et al., 2016; Windebank and Horodnic 2017), regions of the European Union (Williams and Horodnic 2015, 2017b) and the EU as a whole (Williams and Horodnic 2017a; Williams et al., 2015), confirm that the higher the level of vertical trust, measured in terms of tax morale, the lower is the likelihood of participation in undeclared work.

Therefore, this approach explains engagement in undeclared work to result from low levels of vertical trust (i.e., trust in the state by citizens), resulting in a low intrinsic motivation to pay taxes, measured in terms of tax morale (Alm and Torgler, 2006, 2011; McKerchar et al., 2013; Torgler, 2011; Torgler and Schneider, 2007; Williams and Shahid, 2016). In this approach, therefore, the goal is to increase vertical trust to improve the commitment of citizens to voluntarily comply (Kirchler, 2007; Torgler, 2011). In consequence, reductions in undeclared work are pursued by encouraging greater self-regulation.

In recent years, moreover, it has started to be argued that participation in undeclared work is not only determined by the level of vertical trust (between government and citizens) but also the level of horizontal trust (between citizens), in the form of trusting other individuals to be compliant (Baric, 2016; Williams et al., 2017). Here, individuals can be argued to be more likely to engage in undeclared work if they live in a community where undeclared work is considered widespread, not least because they might then be less worried about the sanctions and risk of detection, but also because they might consider that everybody else does it so why should they be compliant. Table 2 summarises the studies on this social actor approach and their findings. 
Table 2. Studies of social actor approach

\begin{tabular}{|c|c|c|}
\hline Relationship & Result & Studies \\
\hline $\begin{array}{l}\text { Relationship between vertical } \\
\text { trust and participation in } \\
\text { undeclared work }\end{array}$ & $\begin{array}{l}\text { Greater vertical } \\
\text { trust reduces } \\
\text { participation }\end{array}$ & $\begin{array}{l}\text { Alm and Torgler, 2006, 2011; Kirchler 2007; Torgler 2007, } \\
\text { 2011; McKerchar et al., 2013; Williams and Franic 2015, 2016; } \\
\text { Williams and Horodnic 2015, 2017a,b; Williams and Shahid, } \\
\text { 2016; Williams et al., 2015, 2016; Windebank and Horodnic } \\
2017\end{array}$ \\
\hline $\begin{array}{l}\text { Relationship between horizontal } \\
\text { trust and participation in } \\
\text { undeclared work }\end{array}$ & $\begin{array}{l}\text { Greater horizontal } \\
\text { trust reduces } \\
\text { participation }\end{array}$ & $\begin{array}{l}\text { Laboratory experiments (not surveys) conducted by: Alm, } \\
\text { 1999, 2012; Alm et al., 1999; Ajzen, 1991; Chang and Lai, } \\
\text { 2004; Fellner et al., 2013; Hallsworth et al., 2017; Lefebvre et } \\
\text { al. 2015; Traxler, } 2010\end{array}$ \\
\hline
\end{tabular}

Indeed, laboratory experiments reveal that taxpayers' inclination to comply depends on the behaviour of their fellow citizens (Ajzen, 1991; Chang and Lai, 2004; Traxler, 2010) and that individuals are more likely to comply if tax compliance is the social norm (Alm, 1999, 2012; Alm et al., 1999). For example, a laboratory experiment in three European countries (Belgium, France, and the Netherlands) reveals that for participants receiving information about low compliance, evasion increased significantly, but for those receiving information about high compliance, evasion did not result (Lefebvre et al. 2015). In two further experiments conducted in the UK (Hallsworth et al., 2017) and Austria (Fellner et al., 2013), the level of compliance increased after the experimental groups received a letter informing them about the high compliance of their peers. Therefore, individuals are conditionally cooperative; their compliance is conditional upon the behaviour of others (Traxler, 2010). When citizens perceive that a large majority of citizens are breaking the formal rules of the game, then the argument is that they too decide to do so. Indeed, the lower the level of horizontal trust (i.e., the greater the perceived propensity of other citizens to be non-compliant), the greater will be likelihood that citizens will themselves act in a non-compliant manner. Until now, however, the findings on horizontal trust are limited to laboratory experiments. No survey data have been reported on the relationship between horizontal trust and participation in undeclared work. To evaluate this social actor approach therefore, the following hypothesis can be tested:

Social actor hypothesis (H2): improving vertical and horizontal trust lowers the likelihood of participation in undeclared work, ceteris paribus.

H2a: improving vertical trust, measured in terms of the level of tax morality, lowers the likelihood of participation in undeclared work, ceteris paribus.

$H 2 b$ : improving horizontal trust lowers the likelihood of participation in undeclared work, ceteris paribus.

\section{Combining the approaches}

In most national governments, including the Czech Republic, which is the focus of this paper, the rational economic actor approach has been the dominant approach; the focus has been upon increasing the probability of detection and penalties (Williams and Puts, 2017). Rather less attention has been until now given to the social actor approach. However, these two approaches are not mutually exclusive. A 'slippery slope' approach argues that governments can pursue not only 'enforced' compliance by increasing the sanctions and probabilities of detection and therefore the power of authorities, but also 'voluntary' compliance and thus trust in 


\section{Articles}

government (Kirchler et al., 2008; Kogler et al., 2015; Kastlunger et al., 2013; Khurana and Diwan, 2014; Muehlbacher et al., 2011; Prinz et al., 2013; Wahl et al., 2010). When there is neither trust in authorities and authorities have no power, the argument is that there will be greater participation in undeclared work. When trust in, and/or the power of, authorities increases nevertheless, engagement in undeclared work declines. Wahl et al (2010) in a laboratory experiment randomly present different participants with four different descriptions of a fictitious country, in which the authorities are portrayed as trustworthy or untrustworthy and as powerful or powerless. They find that participants paid significantly more taxes when both power and trust were high. The outcome has been an argument that combining the two approaches is the most effective way of tackling undeclared work (Kogler et al., 2015; Muehlbacher et al., 2011).

Nevertheless, this ignores the potentially complex interaction effects between increasing the power of authorities and trust in authorities. Applying higher penalties and risks of detection might not always lead to the same outcome. The impacts of increasing the probability of detection and sanctions may vary at different levels of vertical trust. Increasing the risks of detection and penalties might result in greater non-compliance when vertical trust (i.e., tax morality) is high, due to a breakdown of trust between the state and its citizens (Chang and Lai, 2004; Kirchler et al., 2014). In other words, vertical trust might moderate the impacts of increasing the perceived probabilities of detection and sanctions on participation in undeclared work. Until now, however, little if no research has been conducted on their complex interactions and dynamics to move towards a variegated understanding of the interactions between deterrents and vertical trust. Neither has the moderating effects of horizontal trust been analysed. In consequence, the following hypothesis can be here tested:

Moderating impacts of vertical trust hypothesis $(\mathrm{H} 3)$ : the impacts of sanctions and risks of detection on participation in undeclared work will vary according to the level of vertical trust, ceteris paribus.

H3a: the impacts of the perceived penalties on participation in undeclared work will vary according to the level of vertical trust, ceteris paribus.

$H 3 b$ : the impacts of the perceived risk of detection on participation in undeclared work will vary according to the level of vertical trust, ceteris paribus.

Moderating impacts of horizontal trust hypothesis $(\mathrm{H} 4)$ : the impacts of sanctions and risks of detection on participation in undeclared work will vary according to the level of horizontal trust, ceteris paribus.

H4a: the impacts of the perceived penalties on participation in undeclared work will vary according to the level of horizontal trust, ceteris paribus.

$H 4 b$ : the impacts of the perceived risk of detection on participation in undeclared work will vary according to the level of horizontal trust, ceteris paribus.

\section{Methodology}

\section{Data}

To evaluate these hypotheses on explaining and tackling undeclared work, data is reported from the Czech Republic. This comprises 1,000 face-to-face interviews conducted in the Czech Republic between April and May 2013 in the national language with adults aged 15 years and older in Eurobarometer 79.2, and 1,024 face-to-face interviews conducted in Czech Republic between May and June 2007 in the national language with adults aged 15 years and older in Eurobarometer 67.3. A multi-stage random 


\section{Articles}

(probability) sampling methodology was used for these Eurobarometer surveys, ensuring that on the issues of gender, age, region and locality size, the national sample, as well each level of sample, is representative in proportion to its population size. In every household, the 'closest birthday' rule was applied to select respondents, while every subsequent address was determined by the standard 'random route' procedure.

\section{Variables}

To evaluate whether increasing the penalties and risks of detection, and the level of vertical and horizontal trust, reduces the likelihood of participation in undeclared work in the Czech Republic, the dependent variable used is one that examines who engages in undeclared work. This is a dummy variable with value 1 for persons who answered 'yes' to the question in 2007 survey of 'Did you yourself carry out any undeclared activities in the last 12 months for which you were paid in money or in kind?' and to the question in 2013 survey of 'Apart from a regular employment, have you yourself carried out any undeclared paid activities in the last 12 months?', and value 0 otherwise.

To evaluate the relationship between participation in undeclared work and the policy measures, four explanatory variables are used (see Table 3). Firstly, to evaluate whether the perceived risk of detection influences participation, a dummy variable is used describing the perceived risk of being detected when engaging in undeclared work. Secondly, to evaluate how penalties are associated with participation in undeclared work, a dummy variable is used, describing the expected sanctions if caught doing undeclared work.

Thirdly, to evaluate the relationship between participation in undeclared work and the level of vertical trust, measured by tax morality, participants were asked to rate the
Evaluating Policy Approaches Towards Tackling

Undeclared Work in the Czech Republic

acceptability of participating in six types of undeclared work using a 10-point Likert scale (where 1 means absolutely unacceptable and 10 means absolutely acceptable). An aggregate tax morality index for each individual was then constructed by collating participants' responses to the six questions. The Cronbach's Alpha coefficient of the scale is 0.89 and 0.88 for 2007 and 2013 respectively, which shows a good internal consistency of the scale (Kline, 2000). Here, the index is represented in the original 10-point Likert scale format, meaning that the lower the index value, the higher is their tax morality. Tax morale is used to measure vertical trust because a lack of trust in formal institutions is manifested in a low tax morale (Alm and Torgler, 2006; Torgler et al., 2008), so it is a proxy of a lack of vertical trust between citizens and government.

Fourth and finally to evaluate the effect of horizontal trust on undeclared work, participants in both 2007 and 2013 were asked 'Do you personally know any people who work without declaring their income or part of their income to tax or social security institutions?' Those answering value 1, 'yes', means that they perceive others to engage in undeclared work and therefore have lower horizontal trust. This proxy for measuring the horizontal trust has been used in previous studies of participation in undeclared work (Stefanov, Williams, and Rodgers 2017; Williams and Horodnic 2017c; Williams, Radvansky, and Stefanik 2017).

Drawing upon previous studies evaluating participation in undeclared work from both the supply- and demand-side (Williams and Horodnic, 2015a,b), the control variables selected are gender, age, occupation, people $15+$ years in own household, children, difficulties paying bills (only available for 2013 survey), area. The definition of all variables are presented in Table 3. 


\section{Articles}

Table 3. Variables used in the analysis: definitions

\begin{tabular}{ll}
\hline Variables & Definition \\
\hline $\begin{array}{l}\text { Supply of } \\
\text { undeclared work }\end{array}$ & $\begin{array}{l}\text { A dummy variable of undeclared paid activities carry out in the last } 12 \text { months, apart from a regular employment } \\
\text { Expected }\end{array}$ \\
sanctions & $\begin{array}{l}\text { A dummy variable for the penalties associated with participation in undeclared activities with value } 0 \text { for normal } \\
\text { tax or social security contributions due and value } 1 \text { for normal tax or social security contributions due, plus fine } \\
\text { or prison. }\end{array}$ \\
Detection risk & $\begin{array}{l}\text { A dummy variable for the perceived risk of detection with value } 0 \text { for a very small or fairly small risk and value } 1 \\
\text { for a fairly high or very high risk. }\end{array}$ \\
& $\begin{array}{l}\text { Constructed index of self-reported tolerance towards tax non-compliance. Participants were asked to rate the } \\
\text { Vertical trust } \\
\text { acceptability of participating in six types of undeclared work using a 10-point Likert scale (where } 1 \text { means } \\
\text { absolutely unacceptable and 10 means absolutely acceptable), namely: an individual is hired by a household } \\
\text { for work and s/he does not declare the payment received to the tax or social security authorities even though it } \\
\text { should be declared; a firm is hired by a household for work and it does not declare the payment received to the } \\
\text { tax or social security authorities; a firm is hired by another firm for work and it does not declare its activities to } \\
\text { the tax or social security authorities; a firm hires an individual and all or a part of the wages paid to him/her are } \\
\text { not officially declared; someone receives welfare payments without entitlement, and someone evades taxes by } \\
\text { not declaring or only partially declaring their income. An aggregate tax morality index for each individual was } \\
\text { then constructed by collating participants' responses to the six questions. }\end{array}$
\end{tabular}

Horizontal Trust A dummy variable with value 1 for those who actually know someone who undertakes undeclared work and 0 otherwise

Gender A dummy variable with value 0 for females and 1 for males

Age A continuous variable indicating the exact age of a respondent

Occupation A categorical variable grouping respondent by their occupation with value 1 for self-employed, value 2 for employed, and value 3 for not working

People 15+ A categorical variable for people 15+ years in respondent's household (including the respondent) with value 1 years in own for one person, value 2 for two persons, value 3 for 3 persons or more

household

Children A dummy variable for the presence of children up to 14 years old in the household with value 0 for individuals with no children and value 1 for those having children

Difficulties A categorical variable for the respondent difficulties in paying bills with value 1 for having difficulties most of the paying bills time, value 2 for occasionally, and value 3 for almost never/ never

Area A categorical variable for the area where the respondent lives with value 1 for rural area or village, value 2 for small or middle-sized town, and value 3 for large town

\section{Analytical methods}

To evaluate the relationship between participation in undeclared work and the perceived penalties and risk of detection, and the level of vertical and horizontal trust, logistic regression is used. This is because logistic regression analysis is used for testing hypothesis about relationships between a categorical dependent variable and one or more categorical or continuous independent variables. The dependent variable in logistic regression is binary. The maximum likelihood method is used for estimating the least squares function. Logistic regression solves such problems applying the logit transformation. Logistic regression predicts the logit of $Y$ to $X$. Since the logit is the natural logarithm $(\ln )$ of odds of $Y$, and the odds are the ratios of probabilities $(p)$ of $Y$ happening to probabilities $(1-p)$ of $Y$ not happening. The dependent variable in logistic regression can be presented as follows:

$$
Y=\left\{\begin{array}{l}
0 \\
1
\end{array}\right.
$$




\section{Articles}

Let us denote the $\mathrm{m}$ independent variables by the vector $X^{\prime}=\left(x_{1}, x_{2}, \ldots, x_{m}\right)$, then the logistic regression model is given by the following equation:

$$
\begin{aligned}
p(X)_{i}= & \beta_{0}+\beta_{1} S_{i}+\beta_{2} D_{i}+\beta_{3} M_{i}+ \\
& +\beta_{4} H_{i}+\sum_{j=5}^{m} \beta_{j} C V_{i}
\end{aligned}
$$

(Model 1)

Here, $i(1, \ldots N)$ refers to the number of respondents. There are 771 and 779 respondents available for 2007 and 2013 surveys respectively. The dependent variable of the model is UDW represents undeclared paid activities, $S$ represents expected sanction, $D$ represents detection risk, $M$ represents level of tax morality and finally $H$ represents level of horizontal trust. $\mathrm{CV}$ represents the control variables as gender, age, occupation, people $15+$ years in own household, children, difficulties paying bills (only available for 2013 survey), area. Finally, to investigate moderating effects the model we estimate is given by:

$$
\begin{aligned}
p(X)_{i}= & \beta_{0}+\beta_{1} S_{i}+\beta_{2} D_{i}+\beta_{3} M_{i}+ \\
& \beta_{4} H_{i}+\beta_{5}(S * M)_{i}+\beta_{6}(D * M)_{i}+ \\
& \beta_{7}(S * H)_{i}+ \\
& \beta_{8}(D * H)_{i}+\sum_{j=9}^{m} \beta_{j} C V_{i}+e_{i}
\end{aligned}
$$

(Model 2)

The only differences here we create interaction variables as $\left(S^{*} M\right),\left(D^{*} M\right),\left(S^{*} H\right)$, and $\left(D^{*} H\right)$. The logistic regression has the following form:

$$
\begin{aligned}
\operatorname{Logit}(\mathrm{Y}) & =\ln (\text { odds })=\ln \left(\frac{p}{1-p}\right)=\alpha+\beta \mathrm{x} \\
\mathrm{p} & =(\mathrm{Y} \mid \mathrm{X})=\frac{\mathrm{e}^{\alpha+\beta x}}{1+\mathrm{e}^{\alpha+\beta x}}
\end{aligned}
$$

where $p$ is probability of participation in UDW, $\alpha$ is intercept of UDW and $\beta$ is regression coefficient. The logistic regression can also be stated in the form of odds:
Evaluating Policy Approaches Towards Tackling

Undeclared Work in the Czech Republic

$\frac{p_{i}}{1-p_{i}}=\exp \left(\alpha+\beta x_{i}\right)$

\section{Findings}

In 2007, and as Table 4a displays, 6.5\% of Czech Republic citizens reported engaging in undeclared work during the past 12 months. Participation in undeclared work in the Czech Republic is thus lower than EastCentral Europe as a whole but slightly higher than the EU27 as a whole. In 2013, 4.8\% of Czech Republic citizens reported engaging in undeclared work during the past 12 months. In 2013, as in 2007, participation is lower than East-Central Europe but slightly higher than the EU27. Moreover, participation in undeclared work decreased in 2013 compared with 2007 in not only the Czech Republic, but also East-Central Europe and the EU27.

Tables $4 a$ and $4 b$ together reveal the variations between those who participate in undeclared work and those who do not, regarding their perceptions of the expected sanctions, risk of detection and their level of vertical and horizontal trust. In 2007, those participating in undeclared work perceive the expected sanctions as lower than those not engaged in undeclared work; $32 \%$ of those participating in undeclared work consider that only the normal tax or social security contributions will be due if caught compared with $18 \%$ of those not participating in undeclared work. Similarly, $82 \%$ of those doing undeclared work perceive the risk of being detected as very small or fairly small, compared with $79 \%$ of those not participating in undeclared work. Those participating in undeclared work have a lower level of tax morale (5.07) compared with those not engaging in undeclared work (2.75), displaying that their adherence to the laws and regulations are lower. Moreover, $90 \%$ of those participating in undeclared work know others who work undeclared work compared with $42 \%$ of those not participating 


\section{Articles}

in undeclared work. These trends are the same across EU27 or East Central Europe countries. As such, participants in undeclared work view the severity of the punishment as lower, a smaller risk of detection, have a lower level of tax morale and lower level of horizontal trust than those not participating in undeclared work.

In 2013, interestingly, those participating in undeclared work perceive the expected sanctions as higher than those not engaged in undeclared work; $24 \%$ of those participating in undeclared work consider that only the normal tax or social security contributions will be due if caught compared with $25 \%$ of those not participating in undeclared work. $81 \%$ of those doing undeclared work perceive the risk of being detected as very small or fairly small, compared with $74 \%$ of those not participating in undeclared work. Those participating in undeclared work have a lower level of tax morale (4.66) compared with those not engaging in undeclared work (2.90). Moreover, $89 \%$ of those participating in undeclared work know that anyone who works undeclared work compared with $32 \%$ of those not participating in undeclared work. Except for expected sanctions, these trends are the same across EU27 or East-Central European countries. As such, participants in undeclared work view the severity of punishment as slightly higher, a smaller risk of detection, have a lower level of tax morale and level of horizontal trust than those not participating in undeclared work.

For the Czech Republic, comparing 2007 and 2013, unlike participants in declared work, participants in undeclared work began to view the severity of punishment as higher.
Indeed, this reflected the reality; over this period, the level of sanctions for engaging in undeclared work increased (European Platform Tackling Undeclared Work, 2017). There is also a slight increase in the perceived risk of detection, whilst this increase is much more for those who participate in undeclared work. Again, this reflects the changing reality. The effectiveness of inspections improved over this period, not least due to the use of data mining to identify risky-businesses for inspection, which resulted in $30 \%$ of labour inspections identifying violations of labour law (European Platform Tackling Undeclared Work, 2017). Meanwhile, the level of tax morality of those participating in undeclared work increases whilst the level of tax morality of participants who not engage in undeclared work decreases slightly. The latter, in part, can be explained by the fact that increasing penalties and the likelihood of detection seems to have reduced trust in government and lower tax morale due to the way it creates a 'them and us' mentality by treating all citizens as potential criminals (Murphy, 2005, 2008; Murphy and Harris, 2007). Whilst the level of horizontal trust of those participating in undeclared work remains the same, level of horizontal trust among those who do not engage in undeclared work increased. This was perhaps due to a 2 million EUR awareness raising campaign about undeclared work that commenced in 2012 which resulted in 1 million people visiting the campaign webpage and 160,000 visitors the YouTube page (Jarai, 2019; Williams, 2019). This campaign by highlighting the low non-compliance perhaps increased horizontal trust. 
Table 4a. Summary statistics for those participating in undeclared work

\begin{tabular}{|c|c|c|c|c|c|c|}
\hline & \multicolumn{2}{|c|}{ Czech Republic } & \multicolumn{2}{|c|}{$\begin{array}{l}\text { East-Central } \\
\text { Europe }\end{array}$} & \multicolumn{2}{|c|}{ EU 27} \\
\hline & 2007 & 2013 & 2007 & 2013 & 2007 & 2013 \\
\hline Engaged in undeclared work (\%) & 6.5 & 4.8 & 8.2 & 6.8 & 6.2 & 4.5 \\
\hline \multicolumn{7}{|l|}{ Expected sanctions (\%) } \\
\hline Tax or social security contributions due & 32 & 24 & 35 & 49 & 30 & 37 \\
\hline Tax or social security contributions + fine or prison & 68 & 76 & 65 & 51 & 70 & 63 \\
\hline \multicolumn{7}{|l|}{ Detection risk (\%) } \\
\hline Very small/ Fairly small & 82 & 81 & 78 & 72 & 81 & 73 \\
\hline Fairly high/ Very high & 18 & 19 & 22 & 28 & 19 & 27 \\
\hline Tax morality - vertical trust (mean) & 5.07 & 4.66 & 4.27 & 4.61 & 3.75 & 3.74 \\
\hline \multicolumn{7}{|l|}{ Know anyone who works undeclared-horizontal trust (\%) } \\
\hline Yes & 90 & 89 & 89 & 84 & 89 & 85 \\
\hline No & 10 & 11 & 11 & 16 & 11 & 15 \\
\hline \multicolumn{7}{|l|}{ Gender (\%) } \\
\hline Female & 30 & 41 & 38 & 36 & 37 & 37 \\
\hline Male & 70 & 59 & 62 & 64 & 63 & 63 \\
\hline Age (mean) & 38 & 38 & 37 & 37 & 38 & 39 \\
\hline \multicolumn{7}{|l|}{ Occupation (\%) } \\
\hline Self-Employed & 18 & 19 & 14 & 12 & 12 & 12 \\
\hline Employed & 44 & 46 & 50 & 52 & 48 & 43 \\
\hline Not working & 38 & 35 & 36 & 36 & 40 & 45 \\
\hline \multicolumn{7}{|l|}{ People $15+$ years in own household } \\
\hline One & 8 & 13 & 19 & 23 & 22 & 26 \\
\hline Two & 42 & 38 & 42 & 42 & 44 & 42 \\
\hline Three and More & 50 & 49 & 39 & 35 & 34 & 32 \\
\hline \multicolumn{7}{|l|}{ Children (\%) } \\
\hline No children & 92 & 92 & 93 & 94 & 93 & 95 \\
\hline Having children & 8 & 8 & 7 & 6 & 7 & 5 \\
\hline \multicolumn{7}{|l|}{ Area (\%) } \\
\hline Rural area or village & 42 & 24 & 33 & 34 & 38 & 35 \\
\hline Small or middle-sized town & 38 & 51 & 33 & 34 & 35 & 37 \\
\hline Large town & 20 & 25 & 34 & 32 & 27 & 28 \\
\hline \multicolumn{7}{|l|}{ Difficulties paying bills (\%) } \\
\hline Most of the time & - & 18 & - & 22 & - & 20 \\
\hline From time to tome & - & 41 & - & 38 & - & 33 \\
\hline Almost never/never & - & 41 & - & 40 & - & 47 \\
\hline
\end{tabular}

Source: 2013 Eurobarometer 79.2 survey and 2007 Eurobarometer 67.3 survey 
Articles

Table 4b. Summary statistics for those not participating in undeclared work

\begin{tabular}{|c|c|c|c|c|c|c|}
\hline & \multicolumn{2}{|c|}{ Czech Republic } & \multicolumn{2}{|c|}{$\begin{array}{l}\text { East-Central } \\
\text { Europe }\end{array}$} & \multicolumn{2}{|c|}{ EU 27} \\
\hline & 2007 & 2013 & 2007 & 2013 & 2007 & 2013 \\
\hline Not engaged in undeclared work (\%) & 93.51 & 95.25 & 91.85 & 93.21 & 93.76 & 95.52 \\
\hline \multicolumn{7}{|l|}{ Expected sanctions (\%) } \\
\hline Tax or social security contributions due & 18 & 25 & 28 & 40 & 23 & 27 \\
\hline Tax or social security contributions + fine or prison & 82 & 75 & 71 & 60 & 77 & 73 \\
\hline \multicolumn{7}{|l|}{ Detection risk (\%) } \\
\hline Very small/ Fairly small & 79 & 74 & 62 & 57 & 64 & 60 \\
\hline Fairly high/ Very high & 21 & 26 & 38 & 43 & 36 & 40 \\
\hline Tax morality (mean) & 2.75 & 2.90 & 2.80 & 2.87 & 2.35 & 2.26 \\
\hline \multicolumn{7}{|l|}{ Know anyone who works undeclared-horizontal trust (\%) } \\
\hline Yes & 42 & 32 & 44 & 33 & 44 & 34 \\
\hline No & 58 & 68 & 56 & 67 & 56 & 66 \\
\hline \multicolumn{7}{|l|}{ Gender (\%) } \\
\hline Female & 61 & 58 & 63 & 60 & 57 & 54 \\
\hline Male & 39 & 42 & 37 & 40 & 43 & 46 \\
\hline Age (mean) & 48 & 46 & 46 & 46 & 48 & 49 \\
\hline \multicolumn{7}{|l|}{ Occupation (\%) } \\
\hline Self-Employed & 7 & 7 & 6 & 7 & 6 & 7 \\
\hline Employed & 49 & 53 & 46 & 48 & 44 & 43 \\
\hline Not working & 44 & 40 & 48 & 45 & 50 & 50 \\
\hline \multicolumn{7}{|l|}{ People $15+$ years in own household } \\
\hline One & 13 & 19 & 20 & 22 & 22 & 23 \\
\hline Two & 48 & 46 & 43 & 46 & 47 & 49 \\
\hline Three and More & 39 & 35 & 37 & 32 & 31 & 28 \\
\hline \multicolumn{7}{|l|}{ Children (\%) } \\
\hline No children & 95 & 95 & 95 & 95 & 95 & 95 \\
\hline Having children & 5 & 5 & 5 & 5 & 5 & 5 \\
\hline \multicolumn{7}{|l|}{ Area (\%) } \\
\hline Rural area or village & 39 & 32 & 37 & 35 & 36 & 34 \\
\hline Small or middle-sized town & 37 & 43 & 36 & 37 & 37 & 38 \\
\hline Large town & 24 & 25 & 27 & 28 & 27 & 28 \\
\hline \multicolumn{7}{|l|}{ Difficulties paying bills (\%) } \\
\hline Most of the time & - & 11 & - & 12 & - & 13 \\
\hline From time to tome & - & 30 & - & 32 & - & 28 \\
\hline Almost never/never & - & 59 & - & 56 & - & 59 \\
\hline
\end{tabular}

Source: 2013 Eurobarometer 79.2 survey and 2007 Eurobarometer 67.3 survey 


\section{Articles}

To evaluate the hypotheses regarding whether participation in undeclared work is significantly associated with firstly, the level of sanctions and risk of detection and secondly, vertical and horizontal trust, Table 5 reports the results of a logistic regression analysis. Starting with the groups most likely to participate in undeclared work and thus the groups that could be targeted by public policy, in 2007 , men were more likely to participate in undeclared work than women and younger people more likely than older persons. Compared with the self-employed, those in waged employment are less likely to engage in undeclared work. In 2013, meanwhile, the finding is that younger people are more likely to participate in undeclared work than older persons, but gender and occupation have no significant effect on the likelihood of participating in undeclared work.
Evaluating Policy Approaches Towards Tackling

Undeclared Work in the Czech Republic

Examining the relationship between participation in undeclared work and the perceived level of penalties and risk of detection, there is no significant relationship between participation in undeclared work and the perceived level of sanctions (refuting $\mathrm{H} 1 \mathrm{a})$. As such, when respondents perceive the level of sanctions to be higher, this does not result in lower levels of participation in undeclared work. Similarly, there is no significant relationship between the perceived risk of detection and participation in undeclared work, when other variables are held constant (refuting $\mathrm{H} 1 \mathrm{~b}$ ). Therefore, the rational economic actor approach of increasing the level of punishments and risk of detection seems not to influence participation in undeclared work in Czech Republic. The results are the same for both 2007 and 2013.

Table 5. Logistic regressions of the propensity to participate in undeclared work in the Czech Republic

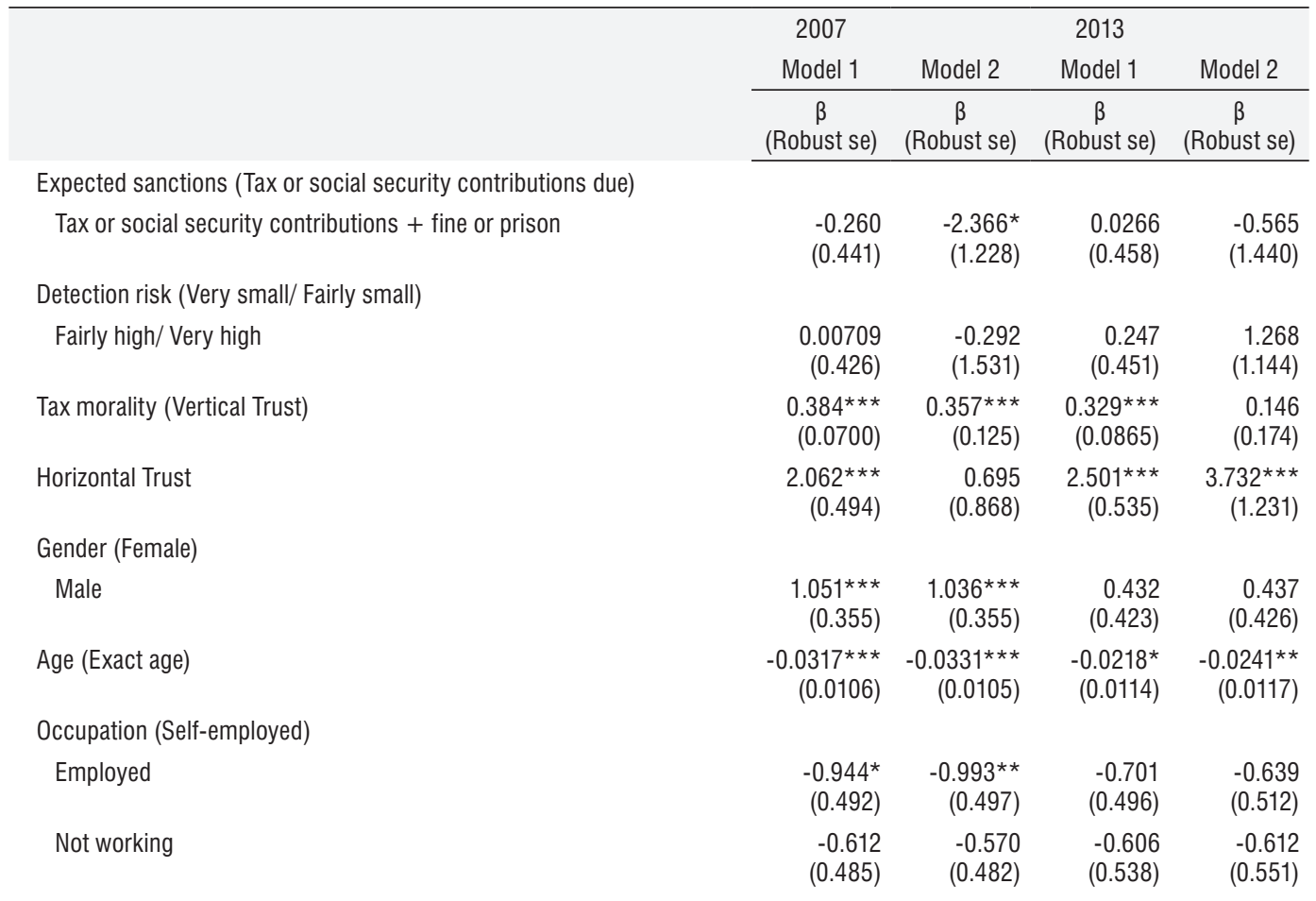


Articles

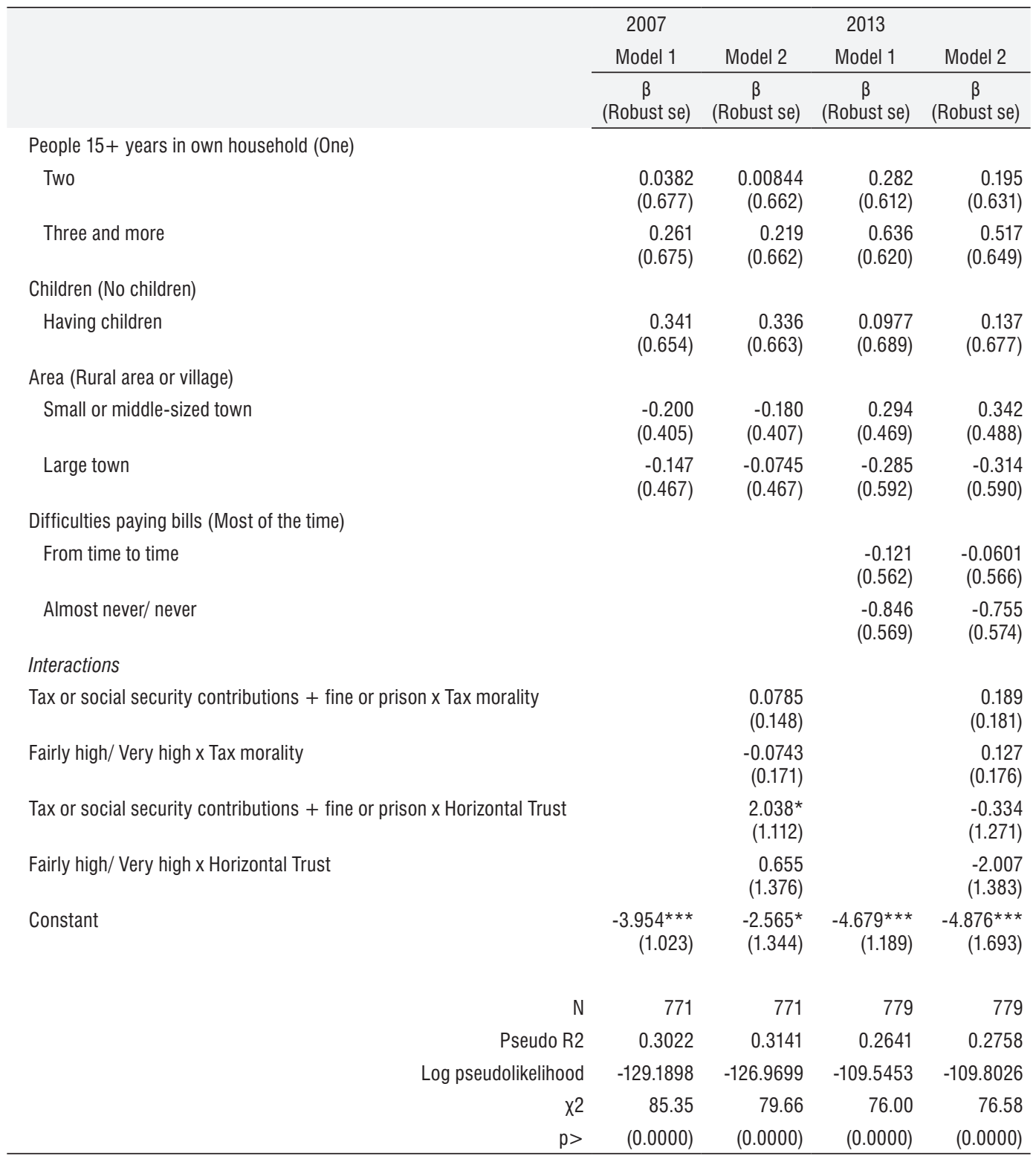

Source: 2013 Eurobarometer 79.2 survey and 2007 Eurobarometer 67.3 survey

Notes: Significant at ${ }^{* *} p<0.01,{ }^{* *} p<0.05,{ }^{*} p<0.1$. Standard errors in parentheses.

All coefficients are compared to the benchmark category, shown in brackets. When multiple imputation techniques are used (ten imputations were simulated through a system of chained equations for every missing value) for addressing the missing responses issue, the same variables are significantly associated with participation in undeclared work. Therefore, we use the available data, with no imputation, to minimize bias.

However, both in 2007 and 2013, morality and horizontal trust. The greater there are significant relationship between participation in undeclared work and tax the laws and regulations, the lower is the 


\section{Articles}

propensity to participate in undeclared work (confirming $\mathrm{H} 2 \mathrm{a}$ ). The greater the level of horizontal trust, the lower is the propensity to participate in undeclared work (confirming $\mathrm{H} 2 \mathrm{~b}$ ). The suggestion, therefore, is that policy interventions based on the rational economic actor approach that seek to increase the level of punishments and risk of detection will have little influence on participation in undeclared work. However, policy interventions based on the social actor approach that seek to improve tax morality and thus trust in the laws and regulations, and horizontal trust, will reduce participation.

Does this mean, therefore, that improving the penalties and risk of detection plays no role in reducing undeclared work in any circumstance? To evaluate this, whether tax morality and level of horizontal trust moderate the impacts and effectiveness of penalties and detection risk is analysed. Model 2 in Table 5 introduces the interaction terms between tax morality and the level of punishment and risk of detection and horizontal trust and the level of punishment and risk of detection. Overall, for 2007, the finding is that the interaction terms between perceived penalties and horizontal trust is significant (accepting $\mathrm{H} 4 \mathrm{a}$ ), while this is not the case for the rest (refuting $\mathrm{H} 3 \mathrm{a}, \mathrm{H} 3 \mathrm{~b}, \mathrm{H} 4 \mathrm{~b}$ ). The impacts of the perceived penalties on participation in undeclared work therefore vary according to the level of horizontal trust. Moreover, model 2 in Table 5 also find a significant relationship between the perceived level of penalties and participation in undeclared work. When respondents perceive the level of sanctions to be higher,
Evaluating Policy Approaches Towards Tackling

Undeclared Work in the Czech Republic

this does result in significantly lower levels of participation in undeclared work.

Moreover, for 2013, overall, the empirical results indicate that the interaction terms between perceived penalties and risk of detection, and tax morality and horizontal trust, are not significant (refuting $\mathrm{H} 3 \mathrm{a}, \mathrm{H} 3 \mathrm{~b}, \mathrm{H} 4 \mathrm{a}$ and $\mathrm{H} 4 \mathrm{~b}$ ). The significant moderating effect between perceived penalties and horizontal trust from 2007 therefore disappeared by 2013.

\section{Discussion and Conclusions}

To evaluate the dominant rational economic actor approach towards explaining and tackling undeclared work and the emergent social actor approach, it has been here analysed in the Czech Republic whether the expected risks of detection and sanctions, as well as level of tax morality and horizontal trust, is associated with participation in undeclared work.

Table 6 summarises the findings. Participation in undeclared work does not significantly decrease as the perceived risks of detection and level of sanctions increase, but does so as tax morality, and thus trust in the laws and regulations, and horizontal trust, improves. This, therefore, tentatively refutes in the Czech Republic the dominant rational economic actor approach and provides support for the social actor approach that focuses upon improving tax morality and horizontal trust. In 2013, moreover, there were no significant interaction effects between the level of penalties and risks of detection, and level of tax morality and horizontal trust. 


\section{Articles}

Table 6. Summary findings of hypotheses

\begin{tabular}{|c|c|c|}
\hline Hypothesis & 2007 & 2013 \\
\hline \multicolumn{3}{|l|}{ Rational economic actor hypothesis (H1): } \\
\hline $\begin{array}{l}\text { H1a: increasing the perceived penalties lowers the likelihood of participation in undeclared work, ceteris } \\
\text { paribus. }\end{array}$ & $\begin{array}{l}\text { Not } \\
\text { confirmed }\end{array}$ & $\begin{array}{l}\text { Not } \\
\text { confirmed }\end{array}$ \\
\hline $\begin{array}{l}H 1 b \text { : increasing the perceived probability of detection lowers the likelihood of participation in undeclared } \\
\text { work, ceteris paribus. }\end{array}$ & $\begin{array}{l}\text { Not } \\
\text { confirmed }\end{array}$ & $\begin{array}{l}\text { Not } \\
\text { confirmed }\end{array}$ \\
\hline \multicolumn{3}{|l|}{ Social actor hypothesis (H2): } \\
\hline $\begin{array}{l}\text { H2a: improving vertical trust, measured in terms of the level of tax morality, lowers the likelihood of } \\
\text { participation in undeclared work, ceteris paribus. }\end{array}$ & Confirmed & Confirmed \\
\hline H2b: improving horizontal trust lowers the likelihood of participation in undeclared work, ceteris paribus. & Confirmed & Confirmed \\
\hline \multicolumn{3}{|l|}{ Moderating impacts of vertical trust hypothesis $(\mathrm{H} 3)$ : } \\
\hline $\begin{array}{l}H 3 a \text { : the impacts of the perceived penalties on participation in undeclared work will vary according to the } \\
\text { level of vertical trust, ceteris paribus. }\end{array}$ & $\begin{array}{l}\text { Not } \\
\text { confirmed }\end{array}$ & $\begin{array}{l}\text { Not } \\
\text { confirmed }\end{array}$ \\
\hline $\begin{array}{l}H 3 b \text { : the impacts of the perceived risk of detection on participation in undeclared work will vary } \\
\text { according to the level of vertical trust, ceteris paribus. }\end{array}$ & $\begin{array}{l}\text { Not } \\
\text { confirmed }\end{array}$ & $\begin{array}{l}\text { Not } \\
\text { confirmed }\end{array}$ \\
\hline \multicolumn{3}{|l|}{ Moderating impacts of horizontal trust hypothesis $(\mathrm{H} 4)$ : } \\
\hline $\begin{array}{l}\text { H4a: the impacts of the perceived penalties on participation in undeclared work will vary according to the } \\
\text { level of horizontal trust, ceteris paribus. }\end{array}$ & Confirmed & $\begin{array}{l}\text { Not } \\
\text { confirmed }\end{array}$ \\
\hline $\begin{array}{l}H 4 b \text { : the impacts of the perceived risk of detection on participation in undeclared work will vary } \\
\text { according to the level of horizontal trust, ceteris paribus. }\end{array}$ & $\begin{array}{l}\text { Not } \\
\text { confirmed }\end{array}$ & $\begin{array}{l}\text { Not } \\
\text { confirmed }\end{array}$ \\
\hline
\end{tabular}

Theoretically, therefore, the contribution of this paper is that it has evaluated in relation to the Czech Republic the dominant rational economic actor approach towards explaining and tackling undeclared work and the emergent social actor approach. The finding is that participation in undeclared work does not significantly decrease as the perceived risks of detection and level of sanctions increase, but does so as tax morality and horizontal trust improves. This tentatively refutes in a Czech Republic context the dominant rational economic actor approach and provides support for the social actor approach.

In terms of the policy implications, the contribution of this paper is to reveal that the conventional rational economic actor approach focused on deterrents needs to be replaced by a social actor approach that focuses upon improving tax morality and horizontal trust. How, therefore, can tax morality be improved? Viewing low tax morality through the lens of institutional theory as a measure of the lack of alignment of the laws, codes and regulations of formal institutions, namely 'state morality', with the norms, beliefs and values of informal institutions, namely 'civic morality' (Helmke and Levitsky, 2004; North, 1990), the suggestion is that there is a need to reduce this institutional asymmetry.

On the one hand, this requires changes in the norms, values and beliefs regarding the acceptability of participating in undeclared work (i.e., civic morality). This can be achieved by educating citizens and raising awareness about the benefits of declared work and the benefits of taxation by connecting this better to the public goods and services received, in order to elicit an intrinsic motivation to comply. Policy initiatives might include government providing citizens with better information on where their taxes have been spent along with 'your taxes are paying for this' signs in hospitals, on ambulances and on public 


\section{Articles}

construction projects. The above analysis reveals the population groups usefully targeted by such campaigns, namely younger people and the self-employed.

On the other hand, changes in formal institutions are needed. As previous studies reveal, compliance improves when there is a sense of procedural justice, which refers to whether citizens perceive the government to treat them in a respectful, impartial and responsible manner (Gangl et al., 2013; Murphy, 2005), procedural fairness, which refers to the extent to which citizens believe that they are paying their fair share compared with others (Molero and Pujol, 2012) and redistributive justice, which refers to whether citizens believe they receive the goods and services they deserve given the taxes that they pay (Kirchgässner, 2011).

On the issue of horizontal trust, perhaps the key implication for policy is that governments should not publish figures on the high level of non-compliance since this has the effect of reducing horizontal trust. Instead, the focus should be upon messages that convey the high level of compliance. The lesson from elsewhere is that such messages are most effective when they relate to the local area and occupation of the citizen concerned (Hallsworth et al., 2017).

Nevertheless, there are limitations to this study. It only examines one country. Caution is required when extrapolating these results to other countries and contexts. For instance, the perception of risk of detection and level of penalties may vary across countries. Whether the results are valid for other countries requires evaluation. Moreover, due to the data set limitations, this study has used two proxies for investigating the relationship between the vertical and horizontal trust and undeclared work. Future studies could investigate this relationship further by measuring the trust in formal institutions directly (along with
Evaluating Policy Approaches Towards Tackling

Undeclared Work in the Czech Republic

undertaking a comparison of the level of trust in different formal institutions) and various forms of horizontal trust beyond the one used in this study (i.e., generalized trust).

In sum, if this paper results in evaluations of these different approaches towards explaining and tackling undeclared work, as well as the complex interplay between them, in other countries, then one of the intentions of this paper will have been fulfilled. If the outcome is that the Czech and other governments consider using other policy approaches and measures when tackling undeclared work beyond the currently dominant rational economic actor approach and its reliance on increasing the penalties and risks of detection, then it will have fulfilled its broader intention. Indeed, the one certainty arising out of this paper is that the Czech government and others can no longer simply assume that the currently dominant rational economic actor approach is the only way of explaining and tackling undeclared work and disregard the role of improving vertical and horizontal trust as a way forward.

\section{References}

Ajzen, I., 1991. The theory of planned behavior. Organizational behaviour and human. Decision Processes, 50, pp. 179-211.

Aliyev, H., 2015. Post-Soviet informality: Towards theory-building. International Journal of Sociology and Social Policy, 35(3-4), pp. 182-98.

Allingham, M. and Sandmo, A., 1972. Income tax evasion: A theoretical analysis. Journal of Public Economics, 1(2), pp. 323-338.

Alm, J., 1999. Tax compliance and administration, in W.B. Hildreth and J.A. Richardson (eds.), Handbook on Taxation, New York: Marcel Dekker, 741-769.

Alm, J., 2012. Measuring, explaining, and controlling tax evasion: Lessons from theory, 


\section{Articles}

experiments, and field studies. International Tax Public Finance, 19(1), pp. 54-77.

Alm, J. and Torgler, B., 2006. Culture differences and tax morale in the United States and in Europe. Journal of Economic Psychology, 27(2), pp. 224-246.

Alm, J., and Torgler, B., 2011. Do ethics matter? Tax compliance and morality. Journal of Business Ethics, 101(4), pp. 635-651.

Alm, J., McClelland, G.H. and Schulze, W.D., 1999. Changing the social norm of tax compliance by voting. Kyklos, 52(2), pp. 141171.

Alm, J., Cherry, T., Jones, M. and McKee, M., 2010. Taxpayer information assistance services and tax compliance behaviour. Journal of Economic Psychology, 31(4), pp. 577-586.

Andrews, D., Caldera Sanchez, A. and Johansson, A., 2011. Towards a Better Understanding of the Informal Economy. Paris: OECD Economics Department Working Paper no. 873, OECD.

Bajada, C. and Schneider, F., 2005. Introduction, in C. Bajada and F. Schneider (eds.), Size, Causes and Consequences of the Underground Economy: an international perspective. Aldershot: Ashgate, 1-14.

Baric, M., 2016. Undeclared work in Croatia: a social exchange perspective. Sheffield: PhD thesis, Management School, University of Sheffield.

Becker, G.S., 1968. Crime and punishment: an econometric approach. Journal of Political Economy, 76(1), pp. 169-217.

Bentham, J. (1788) [1983], Principles of penal law, Reprinted in J.H. Burton (ed.), The works of Jeremy Bentham. Philadelphia: Lea and Blanchard.

Blackwell, C., 2010. Meta-analysis of incentive effects in tax compliance experiments, in $\mathrm{J}$.
Alm, J. Martinez-Vazquez and B. Torgler (eds.), Developing Alternative Frameworks for Explaining Tax Compliance. New York: Routledge, 97-112.

Boels, D., 2014. It's better than stealing: informal street selling in Brussels. International Journal of Sociology and Social Policy, 34 (9/10), pp. 670-693.

Chang, T.-J., and Lai, C.C., 2004. Collaborative tax evasion and social norms: Why deterrence does not work. Oxford Economic Papers, 56(2), pp. 344-368.

Dubin, J.A., and Wilde. L.L, 1988. An empirical analysis of federal income tax auditing and compliance. National Tax Journal, 41(1), pp. 61-74.

European Commission, 2007. Stepping up the Fight against Undeclared Work. Brussels: European Commission.

European Platform Tackling Undeclared Work, 2017. European Platform Undeclared Work Member State Factsheets. Brussels: European Commission.

Feld, L.P. and Frey, B.S., 2002. Trust breeds trust: How taxpayers are treated. Economics of Governance, 3, pp. 87-99.

Fellner, G., Sausgruber, R. and Traxler, C., 2013. Testing enforcement strategies in the field: Threat, moral appeal, and social information. Journal of the European Economic Association, 11, pp. 634-660.

Friedland, N., 1982. A note on tax evasion as a function of the quality of information about the magnitude and credibility of threatened fines: Some preliminary research. Journal of Applied Social Psychology, 12(1), pp. 54-59.

Friedland, N., Maital, S. and Rutenberg, A., 1978. A simulation study of income tax evasion. Journal of Public Economics, 10, pp. 107-116. 


\section{Articles}

Gangl, K., Muehlbacher, S., de Groot, M., Goslinga, S., Hofmann, E., Kogler, C., Antonides, G. and Kirchler, E., 2013. 'How can I help you?': perceived service orientation of tax authorities and tax compliance. Public Finance Analysis, 69(4), pp. 487-510.

Grabiner, L., 2000. The Informal Economy. London: HM Treasury.

Hallsworth, M., List, J.A., Metcalfe, R.D. and Vlaev, I., 2017. The behavioralist as tax collector: Using natural field experiments to enhance tax compliance. Journal of Public Economics, 148, pp. 14-31.

Hartl, B., Hofmann, E., Gangl, K., HartnerTiefenthaler, M. and Kirchler, E., 2015. Does the sole description of a tax authority affect tax evasion? - The impact of described coercive and legitimate power. PLoS One, 10(4), 123-155.

Hasseldine, J. and Li, Z., 1999. More tax evasion research required in new millennium. Crime, Law and Social Change, 31(1), pp. 91104.

Helmke, G. and Levitsky, S., 2004. Informal institutions and comparative politics: a research agenda. Perspectives on Politics, 2, pp. 725-740.

Hodosi, A., 2015. Perceptions of irregular immigrants' participation in undeclared work in the United Kingdom from a social trust perspective. International Journal of Sociology and Social Policy, 35(5/6), pp. 375-389.

Hofmann, E., Hartl, B., Gangl, K. HartnerTiefenthaler, M. and Kirchler, E., 2017. Authorities' coercive and legitimate power: The impact on cognitions underlying cooperation. Frontiers in Psychology, 8(5), pp. 121-144.

Jarai, J., 2019. Awareness raising in Hungary. Paper presented at the European Platform Tackling Undeclared work seminar on
Evaluating Policy Approaches Towards Tackling Undeclared Work in the Czech Republic

preventative approaches, Brussels, April, 2019.

Kaplanoglou, G. and Rapanos, V.T., 2015. Why do people evade taxes? New experimental evidence from Greece. Journal of Behavioral and Experimental Economics, 56, pp. 21-32.

Kaplanoglou, G., Rapanos, V.T. and Daskalakis, N., 2016. Tax compliance behaviour during the crisis: the case of Greek SMEs. European Journal of Law and Economics, 42(3), pp. 405-444.

Kastlunger, B., Lozza, E., Kirchler, E. and Schabmann, R., 2013. Powerful authorities and trusting citizens: the slippery slope framework and tax compliance in Italy. Journal of Economic Psychology, 34(1), pp. 36-45.

Khurana, P. and Diwan, U., 2014. A comparison of psychological factors for tax compliance: self-employed versus salaried people. International Journal in Management and Social Science, 2(3), pp. 107-124.

Kirchgässner, G., 2011. Tax morale, tax evasion and the shadow economy, in $F$. Schneider (ed.), Handbook of the Shadow Economy, Cheltenham: Edward Elgar, 347374.

Kirchler, E., 2007. The Economic Psychology of Tax Behaviour. Cambridge: Cambridge University Press.

Kirchler, E., Hoelzl, E. and Wahl, I., 2008. Enforced versus voluntary tax compliance: the 'slippery slope' framework. Journal of Economic Psychology, 29(2), pp. 210-225.

Kirchler, E., Kogler, C. and Muehlbacher, S., 2014. Cooperative tax compliance: from deterrence to deference. Current Directions in Psychological Science, 23(2), pp. 87-92.

Klepper, S., and Nagin, D., 1989. Tax compliance and perceptions of the risks of detection and criminal prosecution. Law \& Society Review, 23(2), pp. 209-240. 


\section{Articles}

Kline, P., 2000. The Handbook of Psychological Testing. London: Routledge.

Kluge, J.N., and Libman, A., 2017. Sticks or carrots? Comparing effectiveness of government shadow economy policies in Russia. Sarajevo: IOS Working Papers No. 364. Institute for East and Southeast European Studies.

Kogler, C., Batrancea, L., Nichita, A., Pantya, J., Belianin, A. and Kirchler, E., 2013. Trust and power as determinants of tax compliance: Testing the assumptions of the slippery slope framework in Austria, Hungary, Romania and Russia. Journal of Economic Psychology, 34, pp. 169-180.

Leal Ordóñez, J.C., 2014. Tax collection, the informal sector and productivity. Review of Economic Dynamics, 17(2), pp. 262-286.

Lefebvre, M., Pestieau, P., Riedl, A. and Villeval, C., 2015. Tax evasion and social information: An experiment in Belgium, France, and the Netherlands. International Tax and Public Finance, 22(3), pp. 401-425.

Mas'ud, A., Manaf, N.A.A. and Saad, N., 2015. Testing assumptions of the 'slippery slope framework' using cross-country data: Evidence from sub-Saharan Africa. International Journal of Business and Society, 16(3), pp. 408-421.

Mazzolini, G., Pagani, L. and Santoro, A., 2017. The deterrence effect of real-world operational tax audits. Milan: DEMS Working Paper Series No. 359. Department of Economics, Management and Statistics, University of Milan-Bicocca.

McKerchar, M., Bloomquist, K. and Pope, J., 2013. Indicators of tax morale: an exploratory study. eJournal of Tax Research, 11(1), pp. 5-22.

Mohdali, R., Isa, K. and Yusoff, S.H., 2014. The impact of threat of punishment on tax compliance and noncompliance attitudes in Malaysia. Procedia - Social and Behavioral Sciences, 164, pp. 291-297.

Molero, J.C. and Pujol, F., 2012. Walking inside the potential tax evader's mind: tax morale does matter. Journal of Business Ethics, 105(2), pp. 151-162.

Muehlbacher, S., Kirchler, E. and Schwarzenberger, H., 2011. Voluntary versus enforced tax compliance: empirical evidence for the 'slippery slope' framework. European Journal of Law and Economics, 32(1), pp. 8997.

Murphy, K., 2005. Regulating more effectively: The relationship between procedural justice, legitimacy, and tax non-compliance. Journal of Law and Society, 32(4), pp. 562-589.

Murphy, K., 2008. Enforcing tax compliance: To punish or persuade? Economic Analysis \& Policy, 38(1), pp. 113-135.

Murphy, K. and Harris, N., 2007. Shaming, Shame and Recidivism: A test of reintegrative shaming theory in the white-collar crime context. The British Journal of Criminology, 47(6), pp. 900-917.

North, D.C., 1990. Institutions, Institutional Change and Economic Performance. Cambridge: Cambridge University Press.

OECD, 2012. Reducing Opportunities for Tax Non-Compliance in the Underground Economy. Paris: OECD.

Prinz, A., Muehlbacher, S. and Kirchler, E., 2013. The slippery slope framework on tax compliance: an attempt to formalization. Journal of Economic Psychology, 40(1), pp. 20-34.

Richardson, M. and Sawyer, A., 2001. A taxonomy of the tax compliance literature: Further findings, problems and prospects. Australian Tax Forum, 16(2), pp. 137-320. 


\section{Articles}

Schneider, F., 2016. Shadow Economy in Austria - the Latest Developments up to 2016. Linz: Johannes Kepler University of Linz.

Schwartz, R. D. and Orleans, S., 1967. On legal sanctions. The University of Chicago Law Review, 34, pp. 274-300.

Shaw, J., Slemrod, J. and Whiting, J., 2008. Administration \& Compliance. Oxford: Oxford University Press.

Slemrod, J., Blumenthal, M. and Christian, C., 2001. Taxpayer response to an increased probability of audit: Evidence from a controlled experiment in Minnesota. Journal of Public Economics, 79, pp. 455-483.

Stefanov, R., Williams, C.C. and Rodgers, P., 2017c. Tackling Undeclared Work in Southeast Europe: Knowledge-Informed Policy Responses. GREY Policy Brief No. 4, 2017. Accessed February 4 2020. https://ssrn.com/ abstract=3026921.

Torgler, B., 2007. Tax morale in Central and Eastern European countries, in N. Hayoz and S. Hug (eds.), Tax evasion, trust and state capacities: How good is tax morale in Central and Eastern Europe? Bern: Peter Lang, 155186.

Torgler, B., 2011. Tax morale and Compliance: Review of evidence and case studies for Europe. Policy Working Paper 5922. Washington: World Bank.

Torgler, B., and Schneider, F., 2007. Shadow economy, tax morale, governance and institutional quality: $A$ panel analysis. IZA Discussion Paper No. 2563. Bonn: The Institute for the Study of Labor (IZA).

Traxler, C., 2010. Social norms and conditional cooperative taxpayers. European Journal of Political Economy, 26(1), pp. 89-103.

Wahl, I., Kastlunger, B. and Kirchler, E., 2010. Trust in authorities and power to enforce tax compliance: an empirical analysis of the
Evaluating Policy Approaches Towards Tackling

Undeclared Work in the Czech Republic

'slippery slope framework'. Law and Policy, 32(4), pp. 383-406.

Webley, P. and Halstead, S., 1986. Tax evasion on the micro: Significant simulations or expedient experiments? The Journal of Interdisciplinary Economics, 1, pp. 87-100.

Williams, C.C., 2014a. Confronting the shadow economy: Evaluating tax compliance behaviour and policies. Cheltenham: Edward Elgar.

Williams, C.C., 2014b. Out of the shadows: A classification of economies by the size and character of their informal sector. Work, Employment and Society, 28(5), pp. 735-753.

Williams, C.C., 2019. Preventative approaches for tackling undeclared work, focusing upon tax rebates and notification letters. Brussels: European Commission.

Williams, C.C., 2020a. Explaining variations in the magnitude of undeclared work across the 28 European Union member states. Economic Alternatives,

Williams, C.C., 2020b. An institutional theory of tax non-compliance in Bulgaria: a tax morale approach. Economic Alternatives,

Williams, C.C. and Franic, J., 2015. Tackling the propensity towards undeclared work: Some policy lessons from Croatia. South East European Journal of Economics and Business, 10(1), pp. 18-31.

Williams, C.C. and Franic, J., 2016. Beyond a deterrence approach towards the undeclared economy: Some lessons from Bulgaria. Journal of Balkan and Near Eastern Studies, 18(1), pp. 90-106.

Williams, C.C. and Horodnic, A., 2020. Explaining cross-country variations in the degree and intensity of informalisation: an exploratory analysis of 112 countries. Economic Alternatives,

Williams, C.C. and Horodnic, I.A., 2015. Evaluating the prevalence of the undeclared 
economy in Central and Eastern Europe: An institutional asymmetry perspective. European Journal of Industrial Relations, 21(4), pp. 389406.

Williams, C.C. and Horodnic, I.A., 2017a. Evaluating the policy approaches for tackling undeclared work in the European Union. Environment and Planning C: Politics and Space, 35(5), pp. 916-936.

Williams, C.C. and Horodnic, I.A. 2017b. Tackling the informal sector in East-Central Europe. Journal of Tax Administration, 3(2), pp. 65-86.

Williams, C.C. and Horodnic, I.A., 2017c. Under-Declaring Work, Falsely Declaring Work: Under-Declared Employment in the European Union. Brussels: European Commission. http://ec.europa.eu/social/main. jsp? pager offset $=5 \&$ catld $=1299$ \&intPageld $=48$ $75 \&$ langld $=e n$.

Williams, C.C. and Puts, E., 2017. Platform Survey Report: organisational characteristics of enforcement bodies, measures adopted to tackle undeclared work, and the use of databases and digital tools. Brussels: European Commission.

Williams, C.C. and Martinez-Perez, A., 2014. Why do consumers purchase goods and services in the informal economy? Journal of Business Research, 67(5), pp. 802-806.

Williams, C.C. and Schneider, F., 2016. Measuring the Global Shadow Economy: the prevalence of informal work and labour. Cheltenham: Edward Elgar.
Williams, C.C. and Shahid, M., 2016. Informal entrepreneurship and institutional theory: explaining the varying degrees of (in) formalisation of entrepreneurs in Pakistan. Entrepreneurship and Regional Development, 28(1-2), pp. 1-25.

Williams, C.C. and Windebank, J., 1998. Informal Employment in the Advanced Economies: implications for work and welfare. London: Routledge.

Williams, C.C., Horodnic, I.A. and Windebank, J., 2015. Explaining participation in the informal economy: An institutional incongruence perspective. International Sociology 30(3), pp. 294-313.

Williams, C.C., Horodnic, I.A. and Burkinshaw, L., 2016. Evaluating competing public policy approaches towards the informal economy: Some lessons from the United Kingdom. International Journal of Public Sector Management, 29(4), pp. 365-380.

Williams, C.C., Radvansky, M. and Stefanik, M., 2017. Assessment of Under-Declared Employment in Croatia. https://ssrn.com/ abstract $=2983261$.

Windebank, J. and Horodnic, I.A., 2017. Explaining participation in undeclared work in France: Lessons for policy evaluation. International Journal of Sociology and Social Policy, 37(3-4), pp. 203-217.

Witte, AD. and Woodbury, D.F., 1985. The effect of tax laws and tax administration on tax compliance: the case of the U.S. individual income tax. National Tax Journal, 38(1), pp. $1-13$. 